\title{
A Recent History of the Production of Doctorates in Mathematics Education
}

\author{
Barbara Reys and Robert Reys
}

Institutions in the United States have been producing $\mathrm{PhDs}$ in mathematics education for more than a century. Teachers College at Columbia University and the University of Chicago produced the first graduates in mathematics education in 1906 and 1912, respectively [1]. In those institutions, doctoral students in mathematics education typically took courses along with doctoral students in mathematics. However, the dissertation research took a different direction as doctorates in mathematics education focused on issues related to mathematics learning, teaching, or curriculum. Over the past fifty years the nature of doctoral programs in mathematics education has taken many different paths [2], [3], [4], [5]. While some doctoral programs remain in mathematics departments, today the majority of doctoral programs in mathematics education are in colleges/schools of education. Some doctoral programs in mathematics education continue to require a substantial amount of mathematics, while others require very little graduate-level mathematics.

This article highlights the production of doctorates in mathematics education for the past fifty years.

\section{Findings}

Figure 1 shows the annual total number of doctoral graduates in mathematics education from the first Survey of Earned Doctorates (SED) in mathematics education in 1962 to the most recent data available from 2014 [6]. Figure 1 shows annual variability, with several valleys and peaks, ranging from a low of 14 doctoral graduates in mathematics education in 1962 to highs of 153 graduates (1972) and 161 graduates (2009). The steady increase in doctoral graduates in mathematics education during the latter 1960 s and early 1970 s coincided with the "modern mathematics era" and can likely be attributed to the number

Barbara Reys is Curators' Professor Emerita of Mathematics Education, University of Missouri-Columbia. Her email address is reysb@missouri .edu.

Robert Reys is Curators' Professor Emeritus of Mathematics Education, University of Missouri-Columbia. His email address is reysr@missouri .edu.

For permission to reprint this article, please contact:

reprint-permission@ams.org.

DOI: http://dx.doi.org/10.1090/noti1409

\section{Total doctorate recipients}

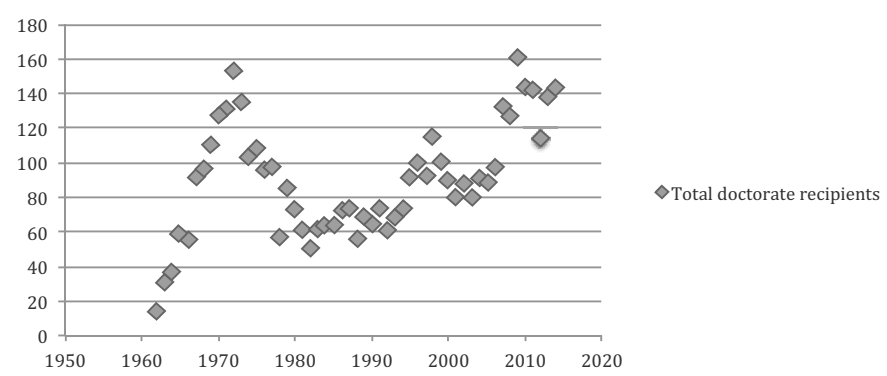

Figure 1. Annual production of doctorates in mathematics education from 1962 to 2014 [6].

of Summer Institutes for K-12 mathematics teachers supported by the National Science Foundation at institutions of higher education throughout the United States during this period [7]. Many middle and secondary mathematics teachers took advantage of these opportunities to pursue a doctorate in mathematics education.

About twenty years later another steady increase occurred in the production of doctorates. This increase might be attributed to a surge in recruitment efforts due to an announced shortage of doctorates in mathematics education in institutions of higher education [8], [9]. In 2000 the National Science Foundation began funding several Centers for Learning and Teaching that were designed, among other things, to increase the production of doctorates in mathematics education. This likely contributed to the steady increase of doctoral graduates in mathematics education during the twenty-first century.

Table 1 provides additional detail regarding the data shown in Figure 1. An examination

\section{Since 1970} there has been a steady increase in the percentage of females earning a doctorate in mathematics education 
Table 1. Summary of total number of doctorates in mathematics education and the number of different institutions awarding the degrees [6].

\begin{tabular}{|c|c|c|c|c|c|c|c|c|c|c|c|}
\hline Years & $1962-64$ & $1965-69$ & $1970-74$ & $1975-79$ & $1980-84$ & $1985-89$ & $1990-94$ & 1995-99 & $2000-04$ & 2005-09 & 2010-14 \\
\hline $\begin{array}{l}\text { Range of \# of graduates } \\
\text { during the } 5 \text {-year period }\end{array}$ & $14-36$ & $56-111$ & $104-153$ & $57-108$ & $50-74$ & $56-74$ & $62-74$ & $92-115$ & $80-91$ & $89-161$ & $114-144$ \\
\hline Total \# of graduates & 81 & 413 & 651 & 444 & 312 & 336 & 343 & 501 & 429 & 607 & 681 \\
\hline Total \# of females \& percent & $\begin{array}{c}17 \\
21.0 \%\end{array}$ & $\begin{array}{c}64 \\
15.5 \%\end{array}$ & $\begin{array}{c}118 \\
18.1 \%\end{array}$ & $\begin{array}{c}149 \\
33.6 \%\end{array}$ & $\begin{array}{c}145 \\
46.5 \%\end{array}$ & $\begin{array}{c}176 \\
52.8 \%\end{array}$ & $\begin{array}{l}192 \\
56.0 \%\end{array}$ & $\begin{array}{c}313 \\
64.5 \%\end{array}$ & $\begin{array}{c}253 \\
59.0 \%\end{array}$ & $\begin{array}{c}381 \\
62.8 \%\end{array}$ & $\begin{array}{c}441 \\
64.8 \%\end{array}$ \\
\hline $\begin{array}{l}\text { Total \# of minorities } \\
\text { \& percent }\end{array}$ & N/A & $\mathrm{N} / \mathrm{A}$ & $\begin{array}{c}11 \\
4.6 \%\end{array}$ & $\begin{array}{c}50 \\
11.3 \%\end{array}$ & $\begin{array}{c}22 \\
7.1 \%\end{array}$ & $\begin{array}{c}33 \\
9.8 \%\end{array}$ & $\begin{array}{c}25 \\
7.3 \%\end{array}$ & $\begin{array}{c}50 \\
10.0 \%\end{array}$ & $\begin{array}{c}75 \\
17.5 \%\end{array}$ & $\begin{array}{c}87 \\
14.3 \%\end{array}$ & $\begin{array}{c}117 \\
17.2 \%\end{array}$ \\
\hline $\begin{array}{l}\text { \# of different institutions } \\
\text { graduating at least one }\end{array}$ & 37 & 63 & 77 & 69 & 63 & 75 & 77 & 105 & 108 & 116 & 129 \\
\hline
\end{tabular}

by 5 -year increments reveals several patterns, the most striking of which is the dramatic change in the gender of recipients of doctorates in mathematics education. Males represented the majority of graduates during the $1960 \mathrm{~s}$ and 1970s. However, since 1970 there has been a steady increase in the percentage of females earning a doctorate in mathematics education. Beginning in 1987 over one half of the recipients of doctorates in mathematics education were female, and that pattern has continued for more than twenty-five years.

Table 1 also provides information on the number of minorities receiving doctorates in mathematics education. The SED identifies minorities as Asian, Black, Native American, or Hispanic but did not start collecting minority data until 1973. The 1975-79 period provides the first full 5-year increment reflecting ethnic status and shows that during the 1970s and 1980s, about 10 percent of the doctoral recipients were classified "minority." This percentage has increased significantly since 2000. Over this period African Americans represent nearly two-thirds of the minority recipients, Hispanics 20 percent, Asians 15 percent, and Native Americans 2 percent.

The increasing number of different institutions awarding doctorates is another pattern shown in Table 1. During the initial time period (1962-64) there were a total of 81 doctoral graduates, and they completed their degrees from thirty-seven different institutions. The number of different institutions awarding degrees has steadily increased over the years, with over one hundred different institutions graduating doctorates in mathematics education during each of the last four 5-year increments.

Table 2 identifies the ten institutions producing the most doctoral graduates for each of the last five decades. An examination of Table 2 shows that Teachers College, Columbia University, has been the highest producer of doctoral graduates in mathematics education, ranking number one in five of the six time periods. Ohio State University has also been among the top ten each period.

Further examination of Table 2 shows that some institutions, such as Illinois State University, have developed into large producers of doctoral graduates in mathematics education during the last two decades, whereas some high producers in earlier decades, such as Wayne State University, are no longer present.

Of further interest is that over one half of the largest producers average less than two doctoral graduates a year, and about one fourth of them average less than one graduate a year over a decade. The SED data reveal that one hundred eighty different institutions graduated at least one doctorate in mathematics education from 2000 to 2014. Further examination showed that about forty-one of these institutions graduated a total of one doctorate in mathematics education, and over one half ( 55 percent) of the institutions graduated a total of five or fewer doctorates during this 15 -year period.

\section{Some Takeaway Points for Doctoral Graduates}

- The number of doctoral graduates in mathematics education has been increasing each decade, with dramatic increases in the last ten years.

- The number of doctoral graduates in mathematics education varies annually but has averaged about 120 during each of the last ten years.

- The majority-over 60 percent-of doctoral graduates in mathematics education are female.

- The percent of minority doctoral graduates in mathematics education has ranged from 5 to 17 percent across the five decades, with African Americans comprising about two-thirds of the minority graduates.

\section{Some Takeaway Points for Institutions}

- The number of different institutions awarding doctorates in mathematics education has been increasing each decade.

- Two institutions (Ohio State University and Teachers College, Columbia University) have consistently ranked among the top ten producers of doctorates in mathematics education in each decade.

- During the last fifteen years (2000-2014) there were one hundred eighty institutions that graduated at least one doctorate in mathematics education. Nearly 40 percent of the institutions graduated just one or two doctorates in mathematics education.

\section{Closing Comments}

This brief history of the production of doctorates in mathematics education documents the changing nature of the doctoral graduates as well as the increasing number of institutions that produce them. Unfortunately, these data do not provide insight into the academic content of the doctoral programs or the nature of the additional 
Table 2. Top 10 (and ties) of institutions producing doctoral graduates in mathematics education for five and one half decades (6). For a listing of the $\mathbf{4 0}$ largest producers of doctoral graduates in mathematics education from 1962 to 2014, see http://tinyur1. com/table2-top40-ties.

\begin{tabular}{|c|c|c|c|c|c|c|}
\hline Rank & $1962-1969$ & $1970-1979$ & 1980-1989 & 1990-1999 & $2000-2009$ & $2010-2014$ \\
\hline 1 & $\begin{array}{l}\text { Oklahoma State } \\
\text { University(43) }\end{array}$ & $\begin{array}{l}\text { Teachers College- } \\
\text { Columbia } \\
\text { University(64) }\end{array}$ & $\begin{array}{l}\text { Teachers College } \\
\text { Columbia } \\
\text { University(52) }\end{array}$ & $\begin{array}{l}\text { Teachers College- } \\
\text { Columbia } \\
\text { University }(70)\end{array}$ & $\begin{array}{l}\text { Teachers College, } \\
\text { Columbia } \\
\text { University(74) }\end{array}$ & $\begin{array}{l}\text { Teachers College- } \\
\text { Columbia } \\
\text { University }(64)\end{array}$ \\
\hline 2 & $\begin{array}{l}\text { Teachers College- } \\
\text { Columbia } \\
\text { University(35) }\end{array}$ & $\begin{array}{l}\text { Ohio State } \\
\text { University(55) }\end{array}$ & $\begin{array}{l}\text { New York } \\
\text { University(33) }\end{array}$ & $\begin{array}{l}\text { University of } \\
\text { Georgia(56) }\end{array}$ & $\begin{array}{l}\text { University of } \\
\text { Georgia(59) }\end{array}$ & $\begin{array}{l}\text { University of } \\
\text { Georgia(43) }\end{array}$ \\
\hline 3 & $\begin{array}{l}\text { Ohio State } \\
\text { University(34) }\end{array}$ & $\begin{array}{l}\text { Florida State } \\
\text { University(53) }\end{array}$ & $\begin{array}{l}\text { University of } \\
\text { Georgia(33) }\end{array}$ & $\begin{array}{l}\text { University of } \\
\text { Texas(49) }\end{array}$ & $\begin{array}{l}\text { Illinois State } \\
\text { University(41) }\end{array}$ & $\begin{array}{l}\text { Rutgers } \\
\text { University(21) }\end{array}$ \\
\hline 4 & $\begin{array}{l}\text { University of } \\
\text { Michigan(33) }\end{array}$ & $\begin{array}{l}\text { New York } \\
\text { University(51) }\end{array}$ & $\begin{array}{l}\text { University of } \\
\text { Texas(33) }\end{array}$ & $\begin{array}{l}\text { Ohio State } \\
\text { University(38) }\end{array}$ & $\begin{array}{l}\text { University of } \\
\text { Texas(32) }\end{array}$ & $\begin{array}{l}\text { Georgia State } \\
\text { University(17) }\end{array}$ \\
\hline 5 & $\begin{array}{l}\text { University of } \\
\text { Illinois(25) }\end{array}$ & $\begin{array}{l}\text { University of } \\
\text { Northern } \\
\text { Colorado(50) }\end{array}$ & $\begin{array}{l}\text { Georgia State } \\
\text { University(25) }\end{array}$ & $\begin{array}{l}\text { Georgia State } \\
\text { University(33) }\end{array}$ & $\begin{array}{l}\text { Florida State } \\
\text { University(31) }\end{array}$ & $\begin{array}{l}\text { North Carolina State } \\
\text { University(17) }\end{array}$ \\
\hline 6 & $\begin{array}{l}\text { New York } \\
\text { University(23) }\end{array}$ & $\begin{array}{l}\text { Indiana } \\
\text { University(49) }\end{array}$ & $\begin{array}{l}\text { Ohio State } \\
\text { University(25) }\end{array}$ & $\begin{array}{l}\text { Florida State } \\
\text { University(26) }\end{array}$ & $\begin{array}{l}\text { Rutgers } \\
\text { University(31) }\end{array}$ & $\begin{array}{l}\text { University of } \\
\text { Missouri(17) }\end{array}$ \\
\hline 7 & $\begin{array}{l}\text { University of } \\
\text { Wisconsin(21) }\end{array}$ & $\begin{array}{l}\text { University of } \\
\text { Texas(49) }\end{array}$ & $\begin{array}{l}\text { Temple } \\
\text { University(21) }\end{array}$ & $\begin{array}{l}\text { Rutgers } \\
\text { University(21) }\end{array}$ & $\begin{array}{l}\text { North Carolina State } \\
\text { University }(25)\end{array}$ & $\begin{array}{l}\text { Illinois State } \\
\text { University(15) }\end{array}$ \\
\hline 8 & $\begin{array}{l}\text { Florida State } \\
\text { University(19) }\end{array}$ & $\begin{array}{l}\text { University of } \\
\text { Georgia(46) }\end{array}$ & $\begin{array}{l}\text { University of } \\
\text { Maryland(21) }\end{array}$ & $\begin{array}{l}\text { American } \\
\text { University(19) }\end{array}$ & $\begin{array}{l}\text { Oregon State } \\
\text { University(23) }\end{array}$ & $\begin{array}{l}\text { Michigan State } \\
\text { University(15) }\end{array}$ \\
\hline 9 & $\begin{array}{l}\text { University of } \\
\text { Virginia(14) }\end{array}$ & $\begin{array}{l}\text { University of } \\
\text { Illinois(41) }\end{array}$ & $\begin{array}{l}\text { Florida State } \\
\text { University(19) }\end{array}$ & $\begin{array}{l}\text { University of } \\
\text { Wisconsin(18) }\end{array}$ & $\begin{array}{l}\text { University of } \\
\text { Maryland(22) }\end{array}$ & $\begin{array}{l}\text { University of } \\
\text { Michigan(14) }\end{array}$ \\
\hline 10 & $\begin{array}{l}\text { University of } \\
\text { Northern } \\
\text { Colorado(14) }\end{array}$ & $\begin{array}{l}\text { University of } \\
\text { Maryland(38) }\end{array}$ & $\begin{array}{l}\text { Boston } \\
\text { University(18) }\end{array}$ & $\begin{array}{l}\text { University of } \\
\text { Oklahoma(18) }\end{array}$ & $\begin{array}{l}\text { Ohio State } \\
\text { University(21) }\end{array}$ & $\begin{array}{l}\text { Ohio State } \\
\text { University(13) }\end{array}$ \\
\hline
\end{tabular}

experiences that ultimately shape the preparation of doctoral graduates in mathematics education.

While it is safe to say that every $\mathrm{PhD}$ in mathematics has successfully completed graduate-level courses in advanced calculus and analysis, it is not possible to identify any specific course(s) with certainty that all doctoral graduates in mathematics education have completed. Additional research into the overall nature of doctoral programs in mathematics education across a wide variety of institutions of higher education is sorely needed.

\section{Acknowledgment}

Research for this article was funded by the National Science Foundation under grant No. 1434442. However, the opinions expressed are the authors' and do not reflect any endorsement by the National Science Foundation.

\section{References}

1. E. F. DonoghuE, Mathematics education in the United States: Origins of the field and the development of early graduate programs. In R. E. Reys and J. Kilpatrick (eds.), One Field, Many Paths: U.S. Doctoral Programs in Mathematics Education, American Mathematical Society/Mathematical Association of America, Washington, DC, 2001, pp. 3-18.

2. J. A. McIntosh and F. J. CRosswhite, A Survey of Doctoral Programs in Mathematics Education, Eric Information Analysis Center for Science Mathematics and Environmental Education, Columbus, Ohio, 1973.

3. R. E. ReYS, R. GLASGOW, G. A. RAGAN, and K. W. Simms, Doctoral programs in mathematics education in the United States: A status report, One Field, Many Paths: U.S. Doctoral Programs in Mathematics Education (R. E. Reys and J. Kilpatrick, eds.),
American Mathematical Society/Mathematical Association of America, Washington, DC, 2001, pp. 19-40.

4. R. E. Reys and J. A. Dossey (eds.), U.S. Doctorates in Mathematics Education: Developing Stewards of the Discipline, American Mathematical Society/Mathematical Association of America, Washington, DC, 2008.

5. R. E. Reys, R. Glasgow, D. Teuscher, and N. NeVEls, Doctoral programs in mathematics education in the United States: 2007 status report, Notices Amer. Math. Soc., 54 (11), 1283-1293, November 2007.

6. National Science Foundation, National Center for Science and Engineering Statistics, NSF/NIH/USED/USDA/NEH/ NASA Survey of Earned Doctorates, special tabulation using NSF's WebCASPAR system (https://ncsesdata.nsf.gov/ webcaspar/), February 2016.

7. J. J. GAllagher, R. E. Floden, and C. ANDERSON, The context for developing leadership in mathematics and science education. In W. M. Roth and K. G. Tobin (eds.), The World of Science Education: Handbook of Research in North America, Volume 1, Sense Publishing, Rotterdam, NL, 2009, pp. 617-630.

8. R. E. Reys and J. Kilpatrick (eds.), One Field, Many Paths: U.S. Doctoral Programs in Mathematics Education, American Mathematical Society/Mathematical Association of America, Washington, DC, 2001.

9. R. E. REYS, Mathematics education positions in higher education and their applicants: A many-to-one correspondence, Notices Amer. Math. Soc. 49 (2), 202-207, February 2002. 


\section{ABOUT THE AUTHORS}

Barbara likes to hike and watch after her new grandchild.

Robert enjoys playing tennis and officiates collegiate-level tennis matches.

\section{Recent volumes from MS]}

Advanced Studies in Pure Mathematics http://mathsoc.jp/publication/ASPM/

Volume 67

Variational Methods for

Evolving Objects

Edited by L. Ambrosio (SNS),

Y. Giga (Tokyo),

P. Rybka (Warsaw),

Y. Tonegawa (Tokyo Tech.)

ISBN 978-4-86497-028-0

Barbara and Robert Reys
Volume 66

Singularities in Geometry

and Topology 2011

Edited by V. Blanloil (Strasbourg),

O. Saeki (Kyushu)

ISBN 978-4-86497-026-6

Volume 65

Algebraic Geometry in East Asia

- Taipei 2011

Edited by J. A. Chen (Taiwan), M. Chen (Fudan),

Y. Kawamata (Tokyo), J. Keum (KIAS)

ISBN 978-4-86497-024-2

Volume 64

Nonlinear Dynamics in Partial Differential

Equations

Edited by S.-I. Ei (Hokkaido),

S. Kawashima (Kyushu), M. Kimura (Kanazawa),

T. Mizumachi (Hiroshima)

ISBN 978-4-86497-022-8

MSJ Memoirs

http://mathsoc.jp/publication/memoir/memoirs-e.html

Volume 34

Discrete Geometric Analysis:

Martin T. Barlow, Tibor Jordán,

Andrzej Zuk

ISBN 978-4-86497-035-8

Volume 33

Moduli spaces of stable

sheaves on schemes:

Masaki Maruyama

ISBN 978-4-86497-034-1

$\nabla \nabla \nabla$ For purchase, visit $\quad \nabla \nabla \nabla$

http://www.ams.org/bookstore/aspmseries

http://www.worldscientific.com/series/aspm

http://www.worldscibooks.com/series/msjm

The Mathematical Society of Japan

34-8, Taito 1-chome, Taito-ku

Tokyo, JAPAN

http://mathsoc.jp/en/ 